\title{
Bacterial Imagination: Seeing the Enemy in the People's Republic of China of the Early 1950s
}

Lu Liu

\section{(2) OpenEdition}

\section{Journals}

Electronic version

URL: https://journals.openedition.org/chinaperspectives/9868

DOI: 10.4000/chinaperspectives.9868

ISSN: 1996-4617

\section{Publisher}

Centre d'étude français sur la Chine contemporaine

Printed version

Date of publication: 1 March 2020

Number of pages: 17-24

ISSN: 2070-3449

\section{Electronic reference}

Lu Liu, "Bacterial Imagination: Seeing the Enemy in the People's Republic of China of the Early 1950s", China Perspectives [Online], 2020-1 | 2020, Online since 01 March 2020, connection on 02 July 2021. URL: http://journals.openedition.org/chinaperspectives/9868; DOI: https://doi.org/10.4000/ chinaperspectives.9868 


\section{Bacterial Imagination: Seeing the Enemy in the People's Republic of China of the Early 1950s}

LU LIU

ABSTRACT: This paper studies the critical role of the microscope in subject formation of early 1950s People's Republic of China. The campaign against alleged germ warfare (xijun zhan 細菌戰) in 1952 politicised the action of seeing the enemy through the discourse of science. Widely used for science education and mass mobilisation for the campaign, the microscope was at once visual technology and an apparatus of power, magnifying hidden and invisible enemies that threatened the new regime. This paper argues that "seeing the enemy" was the hygienic practice of weisheng (衛生), which took on a new meaning of abjection in the early 1950s. By looking into news reports, visual materials, and science writing from this period, this paper proposes a transdisciplinary methodology for studying PRC history that brings together psychoanalysis, visual culture studies, and the history of science and technology.

KEYWORDS: Germ warfare, weisheng, science, visualisation, abjection, subject formation.

\section{2: The germ crisis}

$n$ the early 1950s, the People's Republic of China (PRC) fought its enemies on multiple battlefields: internationally against the American military in the Korean War and domestically against internal threats such as spies and counterrevolutionaries. The sense of division between "us" and "them," stressed through the prevalent trope of war, was reinforced by news of the notorious germ warfare (xijun zhan 細菌戰). In February 1952, People's Daily (Renmin ribao 人民日報), the official newspaper of the PRC, claimed that American troops had air-dropped "poisonous insects that spread germs" near the China-Korean border. ${ }^{1}$ In the following month, newspapers including the Liberation Daily (Jiefang ribao 解放日報), Wenhui Daily (Wenhui bao 文 匯報), and Xinmin Evening News (Xinmin wanbao 新民晚報) depicted an extended invasion of germs from north-eastern China all the way down to the coastal areas, where large numbers of suspicious flies, spiders, and field mice were spotted, leading to the conclusion that the American military was waging a war of germs. The threefold threat - domestic, international, and biological - was conflated to produce an understanding of the enemy across the boundaries of race and species.

The socialist regime immediately responded by launching an anti-germ warfare campaign. Doctors and scientists were sent to the attacked areas for treatment, disinfection, and investigation and brought home first-hand photographs and footage that circulated in the mass media. On the home front, a popular slogan in 1952 equated killing a fly to the patriotic act of killing an American soldier: similar to the vectors of germs, human enemies were also hidden yet harmful to the body (politic), necessitating acute visual and political awareness for national defence. ${ }^{2}$ Massive clean-ups mobilised children and housewives to sweep away potentially pathogenic pests. Public health organs collaborated with local governments to promote vaccination and hygienic living habits. These practices would later be routinised in the PRC's long-term public health project, the Patriotic Hygiene Campaign (Aiguo weisheng yundong 愛國衛生運動) that continues today.

As Ruth Rogaski points out, the communist weapon in the state of emergency was weisheng, which "under the conditions of a biological threat was an excellent vehicle for the realisation of [modernity]" (Rogaski 2004: 286). Translating weisheng as "hygienic modernity," Rogaski demonstrates how the history of public health in Tianjin became entangled with China's vision of modernity and experience of semi-coloniality in the twentieth century. In this context, the anti-germ warfare campaign was yet another moment of hygienic modernity in the form of the Chinese Communist Party's (CCP) mass mobilisation and nationalist education. However, weisheng also took on a new meaning of abjection in the early 1950s, when germs and pests came to be associated with enemies of the regime, and eliminating the enemy began to require both the knowledge and practice of hygiene. Here I draw on Julia Kristeva's theory of "abjection" to complicate weisheng as a psychological mechanism enacted in the PRC's pursuit of political purity. Developed from Mary Douglas's notion of dirt as "matter out of place" (Douglas 1984), Kristeva discusses abjection as the spatial practice of boundary-drawing. Straddling the subjective and material dimensions, the process of abjection produces the subject when "what disturbs identity, system, order" is ejected as unclean (Kristeva 1982: 4). In other words, the abject that has no inherent property is necessary for the formation of subjectivity, which never stabilises as the abject keeps hovering back and reminding the subject of its want.

\footnotetext{
1. “美軍瘋狂散佈細菌” (Meijun fengkuang sanbu xijun, American armies disseminated germs), Renmin ribao, 22 February 1952.

2. “三年來中國人民的衛生事業” (San nian lai Zhongguo renmin de weisheng shiye, Chinese people's public health project in the past three years), Renmin ribao, 27 September 1952.
} 
It is in the sense of abjection that "guarding life," the literal translation of weisheng, registers the meaning of subject formation. According to Rogaski, "guarding life" refers to daily practices of health in pre-modern Chinese medicine and philosophy and thus "is significantly different from its modern parameters" (Rogaski 2004: 23). However, as protecting the population and the nation from contagion rose to political significance in the early 1950s, weisheng gradually became a defensive action and was used to scientifically demarcate the people from the enemy. As this paper will demonstrate, in the anti-germ warfare campaign, "guarding life" not only occurred when germs and pests were wiped out, but also as a "thought reform" cleansing poisonous ideology and its carriers.

This paper investigates the uncanny resonance between "guarding life" and the logic and practice of abjection that was crucial for socialist subject formation. Focusing on the microscope as visual technology and an apparatus of power, I examine the visualisation of germs and pests as politicised enemy-making. By looking into the news reports, visual materials, and science writing of this period, my analysis reveals that, while the distinction between the clean and the unclean was often portrayed as clearcut through the discourses of science and hygiene, bacterial imagination in the anti-germ warfare campaign constantly crossed the border, aligning the socialist subject in an intimate relationship with the abject. The imagination was at once triggered by microscopic images of bacteria and, similar to the sprawling of bacteria colony, invisible to the watchful eye of the state and thus hard to contain. This visual as well as ideological ambivalence points to the multifaceted subject formation in the Cold War era, in which the binary thinking failed to perpetuate the us-them divide.

My focus on visual culture complements the expanding body of scholarship on the cultural production of the Mao era and rethinks the interplay between socialist culture and political campaigns. I follow Xiaobing Tang's recent research that takes seriously the role of the mass viewer as a "historical subject" in the socialist visual culture. Not only were the masses widely portrayed in paintings and posters, they were encouraged to identify and connect to the represented selves (Tang 2015: 23-6). Engaging with Tang's argument on the quasi-mirror stage where the historical subjects sees themselves through visual practices, this paper attends to the other side of the coin - subject formation in the encounter with the bacterial other - and complicates the encounter as a complex, rugged pedagogy rather than a one-sided, unidirectional story.

\section{Guarding the nation with science}

Germ warfare was not an unfamiliar term for Chinese people in 1952. In December 1949, the Soviet-sponsored Khabarovsk trial of twelve Japanese officials associated with Ishii Shiro and his Unit 731 made headlines in the PRC. Seeing in the trial an opportune moment to assert its international status against the post-war US-Japan alliance, the PRC actively propagated the atrocities of Japanese bacteriological weapons (BW) through exhibitions of related images, personal accounts, and undestroyed laboratory objects (Cathcart 2006). In efforts to foster the incipient Sino-Soviet friendship, the propaganda followed the Soviet rhetoric that attributed the belated justice to lingering imperialism from Japan to the US, the latter of which not only omitted important facts on the Japanese BW crimes in the Tokyo Trial, but also attempted to transfer the BW-related experts and technologies to a new military camp in Fort Detrick. ${ }^{3}$ Such conceptualisation of historical continuity infiltrated the 1952 campaign through the constant reminder that Japanese troops used the same germ weapons on Chinese civilians, channelling anti-Japanese sentiment to the ongoing Resist America, Aid Korea (kangmei yuanchao 抗美援朝) movement (Zhongguo renmin baowei shijie heping weiyuanhui 1952; Rogaski 2002: 408-9).

While the 1950 Japan-bashing sought to elicit emotional responses indignation towards Japan and solidarity with the Soviet Union - the antigerm warfare campaign was distinguished by its emphasis on science as a means of political education. ${ }^{4}$ Science first emerged in the campaign's discourse as a solution to remove the threat and dissipate public anxieties. On 23 February, right after the first germ warfare news report, bacteriologists in Beijing gathered to establish an ad hoc defence committee. Led by Tang Feifan 湯飛凡, head of the then National Institute of Biological Products (Zhongyang shengwu zhipin jiandingsuo 中央生物製品檢定所), the committee aimed at promoting epidemic prevention and popularising rudimentary knowledge on germ theory in order to "guard the people and the nation with science." ${ }^{\prime \prime}$ In this vein, the anti-germ warfare campaign overlapped with the state's other educational programs, especially general science dissemination (kexue puji 科學普及) and the popularisation of medical knowledge in public health.

Science soon became a buzzword in international propaganda when the United States and the PRC debated the truthfulness of the germ warfare claim. On 15 March, People's Daily released "indisputable evidence" photographing fallen bombs, clusters of insects, and microscopic images of bacteria isolated from the insects, all allegedly collected from Northeast China and Korea. ${ }^{6}$ Not to be defeated, the New York Times published an entomologist's remarks on these photos, pointing out that the so-called pathogenic and foreign insects were benign and common in Eurasia, and that the entire claim was fabricated through "pseudo-science." The PRC in turn resorted to the Soviet Union and assembled an International Scientific Commission for Investigating the Facts Concerning Bacteriological Warfare in Korea and China (henceforth ISC). ${ }^{8}$ The six-hundred-page ISC report, publicised in September 1952, was at once a scientific study of germ warfare and an investigative document collecting evidence for legal purposes, which the socialist camp claimed to affirmatively conclude the case.

Neither side won the "proof race," ${ }^{19}$ nor did the ISC report close the case of germ warfare, as suspicions about its truth value lasted throughout the Cold War period. In the 1990s, the matter reclaimed historians' interest following the leakage of correspondence between Beijing and Moscow, which seemed to indicate that the whole incident was a communist hoax

3. “揭露美國包庇日本細菌戰犯的罪性” (Jielu Meiguo baobi Riben xijunzhanfan de zuixing, Exposing the crimes of the American cover-up of the Japanese BW), Renmin ribao, 13 March 1951. For historical studies of the post-war legacies of Japanese BW research, see Harris (2002: 149234).

4. The Japan-bashing quickly declined, following Mao Zedong's public speech in the early 1950s that Japanese people were also victims of imperialism and thus should not be blamed. The popular indignation was instead transferred to the lingering American imperialism. For changes in the SinoJapanese relationship in the Mao era, see Koga (2016: 1-32).

5. “北京細菌學家和醫藥衛生科學工作者集會憤怒抗議美軍散布細菌的罪性”(Beijing xijunxuejia he yiyao weisheng kexue gongzuozhe jihui fennu kangyi meijun sanbu xijun de zuixing, Bacteriologists and medical science workers convened in Beijing in protestation of germ warfare), Renmin ribao, 23 February 1952

6. “美國侵略者進行細菌戰的鐵證” (Meiguo qinlüezhe jinxing xijunzhan de tiezheng, Indisputable proof of the American germ warfare crime), Renmin ribao, 15 March 1952.

7. "Red Photographs Exposed as Fakes," New York Times, 3 April 1952.

8. For the PRC's strategies in mobilising international scientists for the ISC, especially Joseph Needham, see Shiwei Chen (2009: 213-47).

9. This military controversy cloaked in scientific investigation coincides with Bruno Latour's observation on the production of facts through the "proof race" as if in a feedback system, in which "once one competitor starts building up harder facts, the others have to do the same or else submit" (Latour 1987: 172). Linking scientific disputes to the arms race, Latour notices elsewhere that the "mutual problem of winning" underlying both competitions paved the way for the technoscience-military network starting in the early Cold War period (Latour 1990: 35). 
(Leitenberg 1998 and 1999). In 1997, Yanhuang chunqiu 炎黃春秋, a liberal magazine in China, published a posthumous memoir by Wu Zhili 吳之理, director of the then Chinese People's Volunteer Army Health Division and one of the investigators of germ warfare. Wu remembered that after his laboratory experiment failed to isolate pathogens from the insects allegedly disseminated by the US military, a telegram from Beijing arrived and asked Chinese scientists to cooperate with the state and "take advantage of this to reinforce health work" (Wu 2013). This piece of personal memory then became an object of historical study, the veracity and accuracy of which has been contested in a similar way to the germ warfare claim.

While a final resolution of the investigation's truth value relies on the declassification of all related archives in the remote future, this paper takes another path to approach this Cold War puzzle by scaling down to examine the domestic reception and circulation of the scientific evidentiary materials produced by the ISC committee. I focus on the ways that PRC mass media translated expert knowledge into what was appropriate for science dissemination, political education, and mass mobilisation. Highlighting the processes through which science and technology engaged with the divisive Cold War ideology on the grassroots level, this approach also brings to the fore nonhuman agents such as germs and pests in socialist subjectivity in formation.

\section{Seeing the enemy through the microscope}

On May 6, People's Daily published an alleged confession by John Quinn, an American prisoner of war, who explained how American troops used insects as "mechanical carriers of various virulent microorganisms" (Quinn 1952). ${ }^{10}$ Among the several hand-drawn pictures in the confession, the article featured a mosquito with its inner and outer stingers labelled in the text as "transmitters of germs". At first sight nothing more than a supplement to words, the illustration takes on a life of its own through visual amplification as if examined through a microscope. Mass media widely circulated similar images of a single enlarged insect or rat marked with parts of the body. These images served as a visual textbook that taught viewers the right way to see the enemy. As Ruth Rogaski notes, this "heightened visual awareness of natural environment" in images of this kind trained people to look at even the smallest pest in a vigilant way as if they were recognising spies (Rogaski 2004: 294). Such visual awareness not only introduced a new mode of seeing through scrutiny, but also, as techniques of knowing, reconfigured power relations between those who taught how to see and those who learned, between the human that saw and the pest that was beholden. Regarded as "unadulterated science," the microscope was an important tool for the CCP's science dissemination and loomed large in the anti-germ warfare campaign (Gross 2016: 93). Pragmatically, the visualising device was useful in recognising the seemingly normal yet pathogen-carrying insects. Looking into the microscope became an iconographic motif in the anti-germ warfare campaign and later a symbol for the rational, scientifically-minded socialist subject.

The microscopic visuality was most prominent in the early PRC's display culture and science education films. The nation-wide Exhibition on Bacteriological War Crimes Committed by the Government of the United States of America (Meiguo zhengfu xijunzhan zuixing zhanlan 美國政府細 菌戰罪行展覽), for example, rearranged scientific evidence of germ warfare for a wider audience. Held in the main building of the Palace Museum, the exhibition received more than 80,000 appointments upon opening and attracted 6,000 people in the first five days. ${ }^{11}$ An entire display room was devoted to "scientific evidence," including samples of examined insects, their photographs, and bacteriological reports (Figure 1). High-resolution images of flies, mosquitoes, spiders, and rats brought the viewer to a defamiliarised encounter with everyday nuisances upgraded to biological weaponry. The pests' unnoticeable antennae and hairy legs were exposed to light in a similar way that the American scheme of germ warfare was disclosed. These close-up photographs were often juxtaposed with microscopic images of bacteria and viruses such as encephalitis and anthrax. Explaining in the caption that these microbes were isolated from the pests, the curation associated the abstract medical terms with the familiar animals. Along with the images, microscopes with prepared slides also invited visitors to look into the device, similar to the way street peep shows lure passers-by.

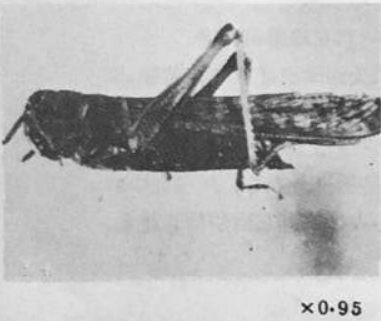

我 蝗

(Locusta mlgratoria Linn.)

我蝗是费作物的大害樱。在自然悄 况下, 它是以帅過冬的, 成患於秋季

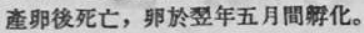
但是一九五二年三月十五日寒冷的氧 候裡，在潘淂市東北人民政府宿舍的 二屡霹天平台上, 發現了很多活的蛙 很影然, 道不是自然產生的, 而 是美軍秀機所㪦作的。

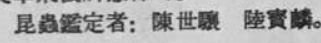

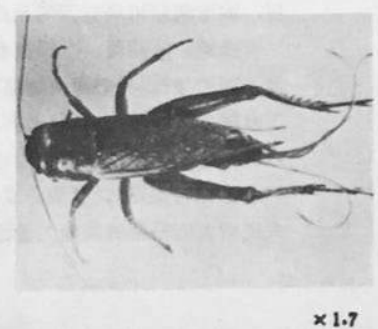

油葫盛

(Gryllus testaceus Walker)

油葫茼是一種以卵過冬的曟作物害

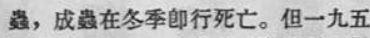
二年三月四日在宽甸雪地發現了大批

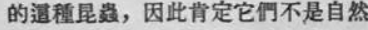
產生的, 而是美國飛機撤佈下來的。 昆霆定者: 朱弘復。

\section{由大家䋗及搖蚊分離出傷寒桿菌}

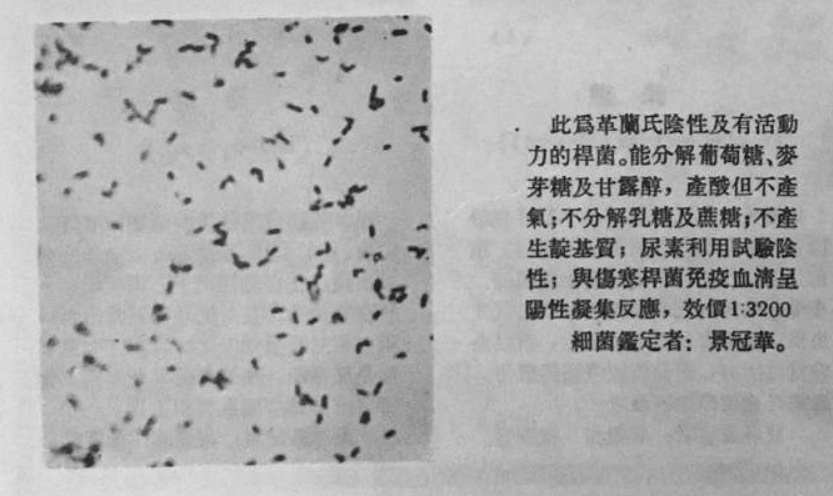

Figure 1. Close-ups of insects (above) and microscopic images (below), from Pamphlet of the Exhibition on Bacteriological War Crimes Committed by the Government of the United States of America, 1952. Credit: Scan provided by the author.

10. The confession mistakenly linked mosquitoes to typhoid disease, which the attached appendix by Chinese scientist Zhong Huilan corrected while emphasising how insects in general could be utilised as "mechanical carriers of various virulent microorganisms." See Zhongguo renmin baowei shijie heping weiyuanhui (1952: 24).

11. See, for example, “不容抵賴的罪證: 美國政府細菌戰罪性展覽會巡禮" (Burong dilai de zuizheng: Meiguo zhengfu xijunzhan zuixing zhanlanhui xunli, Evidence that refuses denial: the nation-wide exhibition on bacteriological war crimes committed by the government of the United States of America), Renmin ribao, 16 September 1952; “參觀展覽會的觀眾極為踴 躍" (Canguan zhanlanhui de guanzhong jiwei yongyue, Visitors are very active in the anti-germ warfare campaign), Renmin ribao, 23 September 1952. 
Magnified out of place and out of scale, the lines and dots on the microscopic slides were at best dubiously recognisable. Feedback on the exhibition reflected how, despite the strategic curation, microscopic images lost their educational potential in the process of abstraction. Reports from the Xinhua News Agency praised the exhibition for stimulating nationalist sentiment and hatred towards American imperialism. The science-oriented rhetoric in the campaign gave way to emotional speeches: visitors were either "indignant" about the crime or "grieved" over the victims, yet there was little mention of the effect of scientific education. In fact, the reception of microscopes in mass education was similarly less effective than expected. As Miriam Gross notes in her study of the schistosomiasis campaign, the PRC's public health movements would continue to use microscopes in inculcating a scientific mindset in mass viewers, who were taught to operate on the optical device, generate their own microscopic visions, and participate in the process of creating scientific images (Gross 2016: 937). ${ }^{12}$ This interactive pedagogy was no better, as the learning outcome often took an unexpected turn: to some viewers, the specimens under amplification "appeared to be monsters" but "disappeared" once the viewer leaped back (ibid.: 158-65). Such confusion is understandable considering the availability of microscopes in the 1950s. While certainly not a rarity in hospitals and research institutions, microscopes were still a novel gadget for non-specialists. For instance, it was not until 1955 that standard biological microscopes started to be manufactured in Shanghai under the supervision of the Chinese Academy of Sciences (Shanghai dianzi yibiao gongye zhi bianzuan weiyuanhui 1999: 274-5). Even after that, the use of scientific instruments was not prevalent in local schools or public health offices. A frequent topic in science journals and magazines such as Science for the People (Kexue dazhong 科學大衆) and Bulletin of Biology (Shengwuxue tongbao 生物學通報) was how to make makeshift microscopes for classrooms and science dissemination purposes.

What impeded science education during the anti-germ warfare campaign, however, was more than the shortage of microscopes. Historical storytelling infiltrated the meaning-making of microscopic images. The anti-germ warfare exhibition explained under an image of anthrax bacilli that the same type of germ was developed by the Japanese Unit 731 during the second Sino-Japanese war, and in this way extended immaterial dimensions of emotion to the medical terms (Rogaski 2002: 386-7). Bacteria thus gained new meanings through the affective ramifications. Through the visualising, amplifying, and exposing logic of the microscope, the enlarged insects and germs pointed to an ongoing war that threatened to infect the new China with fatal diseases, and at the same time gave flashbacks to a traumatic past epitomised by the Japanese bacteriological tests on Chinese people. Remembering this past was meant to evoke collective memory of how China was once invaded and exploited by Japan and, in a longer history, of the Sick Man of East Asia who himself used to be identified as a germ-carrying vector in semi-colonial China's public health projects (Rogaski 2004: 16592). Plagued by war, disease, and foreign powers, modern China's twofold victimisation under imperialism and nature converged and was concretised on the microscopic images of germs.

What the microscope visualised in the anti-germ warfare campaign is the abject at both the material (bacteria) and subjective (trauma) levels. This mechanism of abjection, which exposes and exterminates the enemy through visual practices, operates through "visuality" and participates in "the making of the process of 'history' perceptible to authority" (Mirzoeff 2011: 3). Inculcating a politicised understanding of germs, the campaign's central task, relies on the discourse of science that is deeply inflected by the
CCP's narrative of history. The microscope also embodies what jill Casid calls a "scene of projection" that produces the subject through an apparatus of power (Casid 2015: 1-34). In her study of Enlightenment visual technology, Casid reveals the role of machines in conflating "projection" as psychological mechanism and "projection" as a new way of seeing in the eighteenth century. The rational subject forms through optical devices such as the magic lantern and the telescope, which transport the vulnerable and material body to a projected fantasy of rationality. The resultant "regime of rational vision" nonetheless remains unstable, as what threatens the fortress ego keeps reminding the subject of its affective and sensory susceptibility to the imagined "other" (ibid.: 89-124). In 1952, three years after the founding of the PRC and the proud announcement that "the Chinese people have stood up," the abject past was projected through the microscope to an image of a healthy and strong national body. The national trauma resurfaced only to be erased in the anti-germ warfare campaign's underlying discourse that only the CCP could save China from diseases and poverty.

In Chinese history, bacterial imagination associated with the microscope could be traced back to the Manchuria Plague in 1910. Biomedicine played a decisive role in containing the plague, thanks to the British-trained doctor Wu Lien-The, who first discovered under his microscope that the bacilli pestis solely existed in the victims' lungs, rather than in the blood or under skin as in other cases of plague (Lei 2014: 21-44; Summers 2012). Based on Wu's conclusion, the following anti-plague control escalated in its rigorous restrictions on everyday contact. More importantly, microscopic examinations, rather than checking symptoms, became the only legitimate standard in diagnosis. Wu's discovery helped to stop the rampant plague and temporarily relieved the then collapsing Qing from its sovereign crisis in Manchuria. As Sean Hsiang-lin Lei points out, what stopped the epidemic was the microscope that could pinpoint the bacilli and, by doing so, human vectors (Lei 2014: 43). The plague thus generated an epistemic connection of the microscope with the power to cure, and of scientific visuality with the right to rule. Modern Chinese history after 1911 saw entrenching efforts to bring biomedicine in conflict with indigenous medical knowledge, marking the plague as the watershed in the history of medicine.

The magic of the microscope was further amplified in the popular literature and culture of the Republican era, especially cartoons, medical fiction (yixue xiaoshuo 醫學小説), and audio-visual education. The rising awareness of disease transmission was accompanied by imagination about bacteria as animated, evil beings that corroded both the individual body and the nation. Part of the public imagination was utilised in the Nationalist Government's promotion of science and education films in the 1930s. Envisioning cinema as the modern tool of citizen-making, Chen Guofu 陳 果夫 and Chen Lifu 陳立夫 collaborated on a docu-fictional film, Drinking Water Hygiene (Yinshui weisheng 飲水衛生), in $1934 .{ }^{13}$ The story reflexively features a patriotic intellectual who guides villagers to examine water quality under microscopes and initiates them into hygienic ways of life. For the then movie-goers, the film screen served as a second layer of the microscope showing the bacteria.

The comic from a 1936 Modern Sketch magazine best visualised these affective ramifications (Figure 2). Commenting on the minuteness and immanence of bacteria, the pessimistic cartoonist was concerned that "a protracted war with bacteria is inevitable if future science cannot

12. The exhibition was an important way of propaganda for the state to eliminate superstition in socialist China. See Ho (2017: 103-37).

13. Chen Guofu 陳果夫. 1934. “飲水衛生” (Yinshui weisheng, Drinking water hygiene), Minzhong jiaoyu tongxun 民眾教育 3(10): 157-61 
exterminate them once and for all." Fortunately, by seeing the harmful little beings through the microscope, humankind could at least learn about its enemies. The paradox of relying upon a scientific device yet doubting the overall power of science was further belied in the so-called microscopic images, in which "pathogens" took the forms of ammunition, rats, dancing ghosts, people in a swim pool, and naked women, each representing a related symptom or route of infection of certain contagious diseases. In addition to their medical terms, each type of bacteria also corresponded to one social problem in China. Tetanus, for example, was explained as "caused by bacilli entering the body from a wound, spreading to other organs through blood vessels and lymph, and attacking the central nervous system after an incubation period of four to ten days." Because of the rapid spread of tetanus bacilli to occupy and possess the body, the disease's social counterpart was "corruption," illustrated as a crouching nine-handed monster surrounded by bags of money. Instead of repressing fear, anxiety, and surmise about bacteria, the scientific apparatus of the microscope magnified them, channelling the speculation of the unknown to a form of psychic as well as medical knowledge.

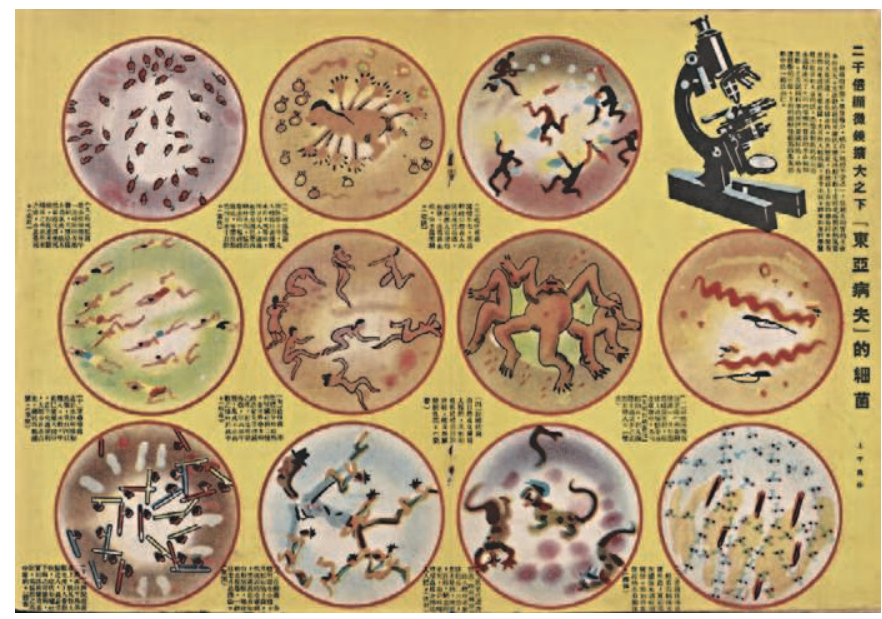

Figure 2. "Bacteria of Sick Man of East Asia under a 2000x microscope." Modern Sketch, 1936. Credit: Scan provided by the author.

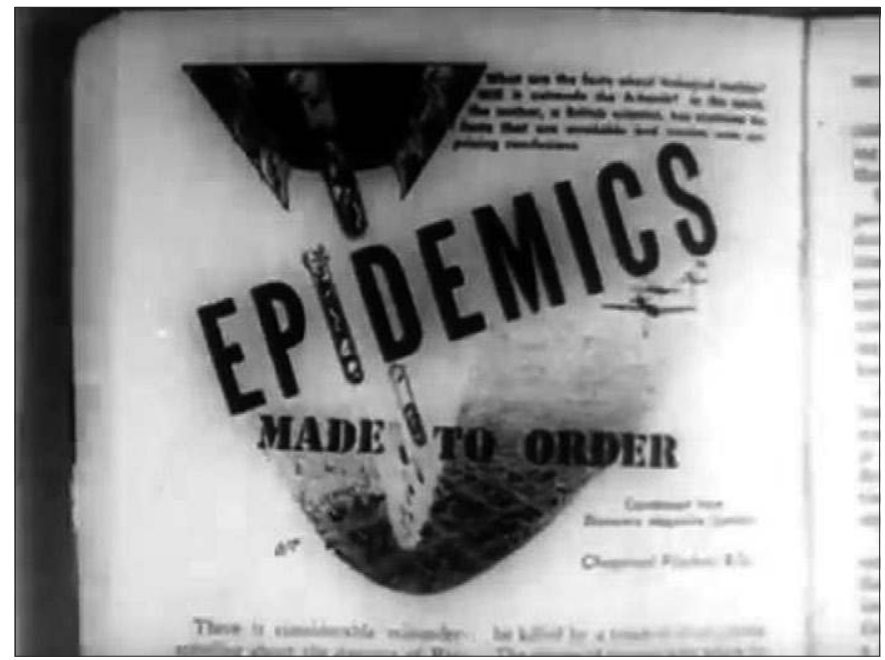

Figure 3. Close-ups in Oppose Biological Warfare. Credit: Screenshot provided by the author.

\section{Oppose Biological Warfare and anxieties of the scientists}

So far, my examination of the microscope takes the anti-germ warfare campaign as an event wherein discourses of science, hygiene, trauma, and national security co-produced the socialist subject through abjection. The last section will focus on scientists, an intriguing group of the socialist subject that both participated in and was constantly recast in the campaign. The work of scientists was carefully documented in Oppose Biological Warfare (Fandui xijunzhan 反對細菌戰), a collaborative film by the Beijing Film Studio and North Korean Film Studio. Translated into multiple languages and screened for an international audience, Oppose Biological Warfare epitomised the central role of science and the scientific spirit during the germ warfare investigation and "demonstrate[d] scientific capabilities and achievements" (Johnson 2011: 45). As a result, the filmmakers were asked to respect the law of science at the sacrifice of cinematography. As the director Shi Dongshan 史東山 remembered, some persuasive and "touching" scenes were deleted because they were not scientifically corroborated (Shi 1952). The principle of science also operated on the narrative timeline. Instead of clarifying that footage was collected from various investigation trips, the film abstracted a procedure of scientific research in the sequence of collecting data (fieldwork and interviews), examining data (laboratory scenes), and verifying data (fact-checking in interrogations of American prisoners of war).$^{14}$ The higher order of science-in-action superseded the natural chronology of events, producing a coherent story highlighting how scientists were supposed to conduct research.

Oppose Biological Warfare brimmed over with anxieties over the effectiveness of science education. It painstakingly taught the audience what to see and how to see on the screen through the cinematic technique of amplification. When showing an illustration from the 1950 American journal Science Digest of test tubes being dropped from the air, the camera not only shoots at the image, but also pulls closer to the tube, showing details of insects and germs that are likely to go unnoticed without the cinematic technique of zooming in (Figure 3). In another scene, the filmmakers mark

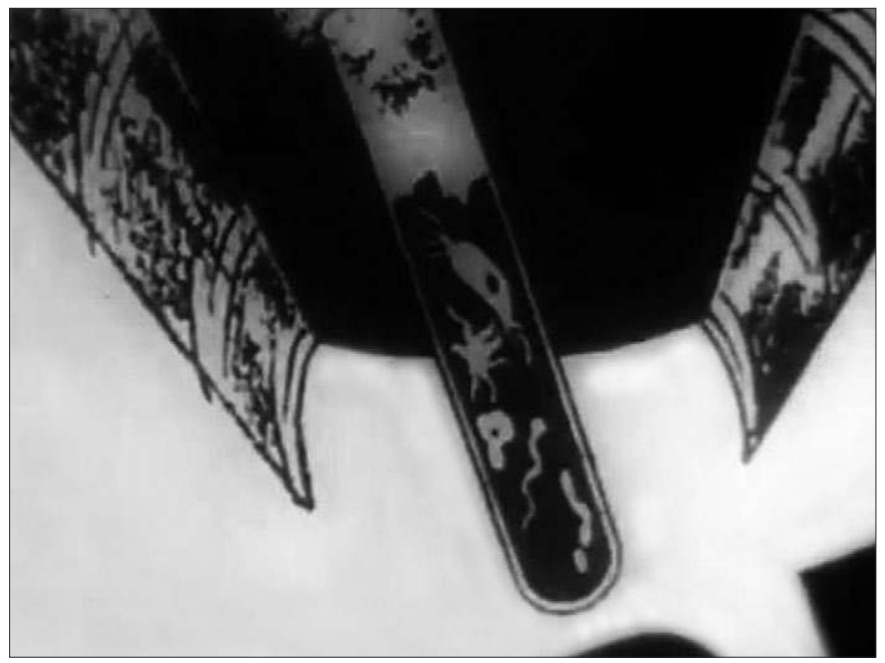

14. The three germ-warfare investigations were respectively by an All-Chinese Inquiry Commission on the Bacteriological War Crimes of U.S. Imperialism (Meiguo diguozhuyi xijunzhan zuixing diaochatuan 美國帝國主義細菌戰罪性調查團), the Soviet-assembled International Association of Democratic Lawyers, and the ISC. For different tasks and accomplishments of the three investigations, see Lockwood (2009: 159-93). 
a microscopic image with arrows pointing to the "real pathogens," followed by texts from the bacteriological report that re-interprets the previous shot. Signs and words come to the rescue when images, subject to a diverse array of interpretations, could hardly pinpoint the right message.

Similar anxieties percolate into the depiction of scientists in relation to the masses. In Oppose Biological Warfare, scientists played a twofold role of researcher in the laboratory and instructor of medical knowledge to the surrounding masses. Yet this mentor-student relationship also assumed a problematic hierarchy where the masses needed the guidance and thus were inferior to the scientists. In reality, the precarious relationship was soon to be reversed when the PRC shifted its focus from the science-centred antigerm warfare campaign to the mass mobilisation of the Patriotic Hygiene Campaign, transferring agency from the scientists to "a people's war" (Lynteris 2013: 20-3) $)^{15}$. As if prescient of this change, the film intentionally bonds the scientists with the viewing masses through its camera language. In a lab test on a smeared slide of typhoid bacilli, the camera changes from a frontal shot to a perspective shot so that the audience could see from the perspective of the female researcher (Figure 4). The cinematic act of seeing is simultaneously a representation of science and a scientific activity itself. In this carefully staged "theatre of proof" that compresses science

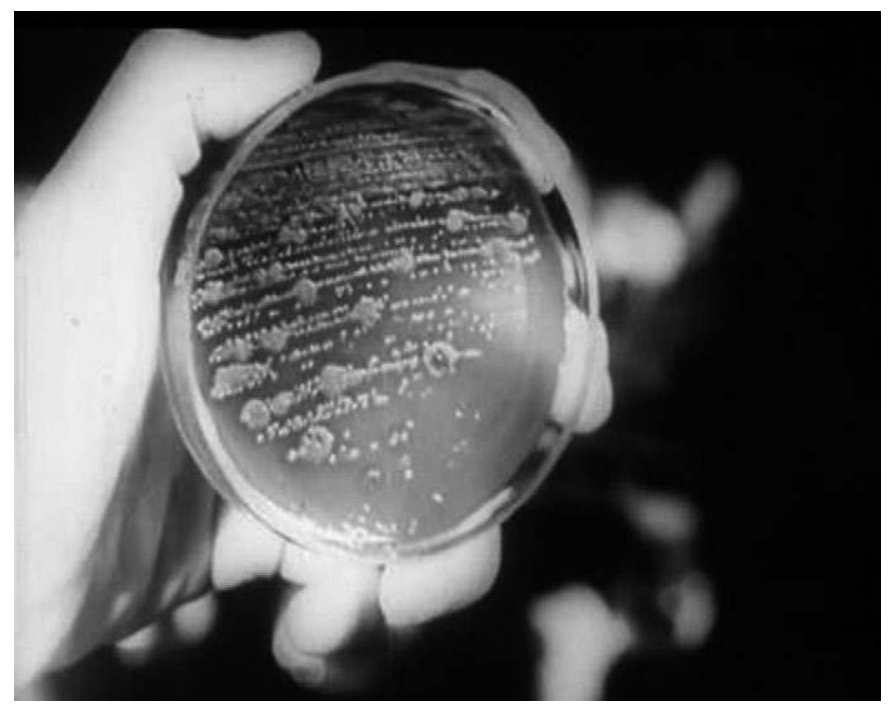

Figure 4. Camera language in Oppose Biological Warfare. Credit: Screenshot provided by the author.

with pedagogy, the female researcher, together with the audience, needed the instruction of her male partner to observe the pattern of the bacteria colony. ${ }^{16}$ It was only through the guidance of those from a higher status, perhaps a delegate from the CCP, that the scientists and the masses gained the right way of seeing.

The prevalent anxieties in the film externalised what baffled the scientists and the filmmakers outside the film, in an intensive political context that identified them as people with questionable loyalties to the regime. In particular, scientists occupied an ambiguous zone in the early 1950s. On the one hand, they were pioneers in the germ warfare investigation and were featured prominently in the mass media. On the other, they were under the first wave of Thought Reform (Sixiang gaizao 思想改造), which, starting in 1951, re-educated intellectuals with revolutionary ideology. ${ }^{17}$ In a language of medicalisation, the movement diagnosed the intellectuals as emotionally identified with the capitalist and the imperialist rather than with the people. In response, the re-educated intellectuals in their self-examinations often underwent an inward anatomy exposing pollution ( $w u$ 污) and toxins ( $d u$
毒) in order to remove the bad tissues. ${ }^{18}$

Amidst the waves of criticism and self-criticism, the liquidation of proAmerican feelings expressed as "America intimacy" (qinmei 親美) and "America worship" (chongmei 崇美) put those with Western educational background in a particularly vulnerable state. 19 "American intimacy" referred to the problematic identification of the scientists with America rather than the PRC, often expressed as the pursuit of "science for science's sake" and "American standards" and the lack of comradeship with the workerspeasants-soldiers. ${ }^{20}$ To dissociate oneself from problematic emotions towards America, the scientists needed to publicly disavow all affiliation with Western ideology and institutions. Because of the political education that Chinese scientists received domestically, the scientists' participation in the ISC investigation was often cast as coerced complicity with the state, as Wu Zhili's memoir indicates. Ironically, the issue is still divisive in the postCold War era, between the consensus outside the PRC that germ warfare was a communist trick and voices inside China supporting the validity of the investigation. $^{21}$

Rather than taking side on the binary question, I propose to take seriously the scientists' intriguing and ambivalent role as an affective dimension of abjection. The scientists had to perform self-disavowal in order to be

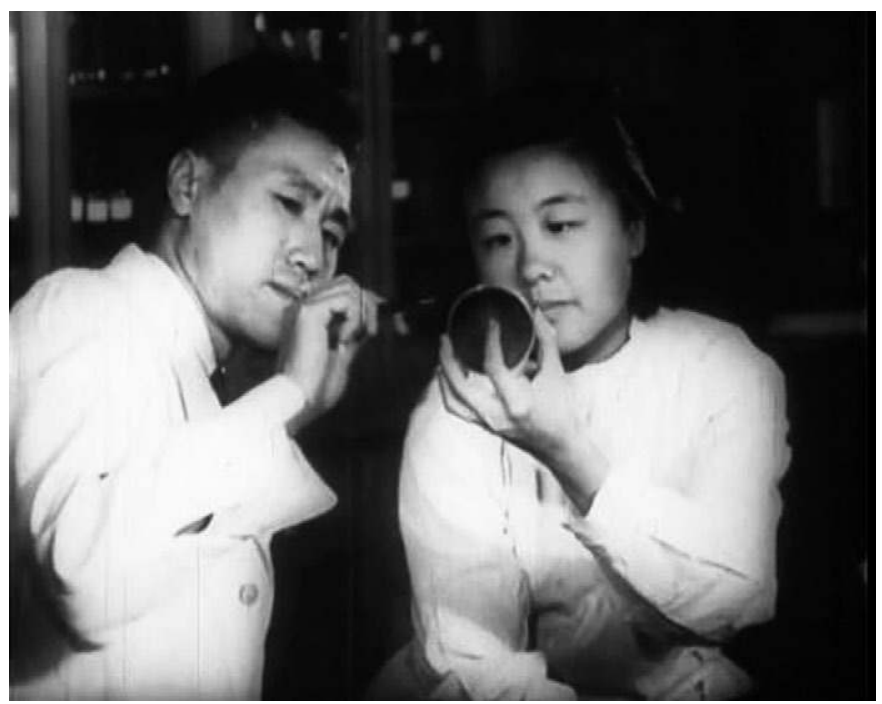

15. Science popularisation (kexuepuji 科學普及 or kepu 科普) in socialist China was characterised by the dynamic of "top-down" and "bottom-up," and complicated the scientist-masses binary through its interrelated individual and institutional actors. See Schmalzer (2008: 55-8, 113-36).

16. "Theatre of proof" is Bruno Latour's phrase on the display of scientific facts both as a critical step for science's dissemination, but also as an effective pedagogy. See Latour (1988).

17. Mao Zedong made explicit in the Chinese People's Political Consultative Conference in 1951 that "Thought Reform was first and foremost the thought reform of intellectuals." Quoted in Yu (2001: 203).

18. Cao Yu, for example, in his self-criticism announced that he "will have to surgically remove the ulcer in my thought" (Cao 1950).

19. This was under the broader movement among intellectuals to criticise the "cultural invasion" (wenhua qinlüe 文化侵略) of the United States (Yu 2001: 58-62; Cheek 2015: 113-59).

20. For example, in 1951, Science Bulletin (Kexue tongbao 科學通報), the PRC's top science journal, reprinted the aquatic biologist Wang Jiaji's apology and self-criticism from People's Daily. Wang reflected upon the pursuit of "absolute scientific objectivity" in his own research and among his colleagues in the Chinese Academy of Sciences (Wang 1952).

21. Immediately after Wu's memoir, the official website of "Memorial of the War to Resist America and Aid Korea" (抗美援朝紀念館 kangmeiyuanchao jinianguan) published an article questioning Wu. See “堅持唯物史觀, 歷史不容纂改” (Jianchi weiwu shiguan, lishi burong zuangai, Sticking to historical materialism; history does not tolerate distortion), http://www.kmycjng.com/newslist. aspx $? \mathrm{c}=6$ A4ECC85774564F8\&id $=5$ C2FDEA97A90129B \&a=s (accessed on 28 November 2019). For other scientists' memoirs or interviews that supported the validity of the germ warfare claim, see Qiu (1993), Lan (2001), and He (2010). 
recognised as socialist subjects. What complicates the case is, first, the fact that the scientists themselves were "vectors" of the ideologically problematic thought, and second, their close contact with the toxic, the pathogenic, and the abject during the germ warfare investigation. Nayoung Kwon points out in her study of colonial Korea that "recognition and desire" in the situation of disavowal produced intimate relationship between "collaborationist" Korean writers and the colonial Japanese power (Kwon 2015: 80-98). Kwon's argument is pertinent here in revealing "intimacy" as a psychic symptom in the process of abjection. Similarly, the improper intimacy that the Chinese scientists were accused of was visually reinforced and inadvertently belied in Oppose Biological Warfare. The film introduces the laboratory scene through quick shots alternating between a scientist's portrayal and closeup of the animal examined by the scientist. Such pairings repeat throughout the film, forming a visual pattern to identify the scientist with the pest. As the scientists were all depicted in the typical pose of looking into the microscope, the line of sight across the screen links the mass viewer's gaze at the scientist with the scientist's gaze at the pest. While the scientists were closely investigating a suspicious pest, they were simultaneously under inspection by the watchful eyes of the state and the masses and were awaiting reports on their categorisation: us or them, friends or foes. The scientists' self-criticism to carefully anatomise their mind found an uncanny reverberation in their anatomy of the abject. The scientists were positioned in a moment of cross-species encounter through cinema, yet another visual technology of amplification and exposure in the regime of the microscope.

\section{Conclusion: The microscope of Mao Zedong Thought}

Towards the end of the Korean War, the PRC steered the anti-germ warfare campaign towards the long-term Patriotic Hygiene Campaign. Targeting five specific toxic creatures, including flies, mosquitoes, rats, mice, and bedbugs, the campaign expanded the scope of the abject from American disseminated insects to all pests in everyday life, and painstakingly habituated the masses to rituals of what Ruth Rogaski calls "public performances" of hygienic modernity, such as sweeping dirt, collective clean-up of public spaces, and regular cleansing of the body (Rogaski 2004: 296). Along with this shift from a discourse of science and patriotism to actions of "doing hygiene," the microscope receded to a supplementary role in public health movements. Yet what the microscope embodied - socialist subjection formation through abjection - continued to drive the wheel of revolution forward. In 1956, the Elimination of Four Pests (Chusihai 除四害) campaign launched a new round of mass killing of flies, mosquitoes, rats, and sparrows. Two years later, it escalated into a "war against nature" under the radicalisation of the
Great Leap Forward (Shapiro 2001; Dikötter 2010). Children became the main force in the campaign and were militarised into mini soldiers. Merciless extermination of animal enemies moulded children into future soldiers, yet also raised questions and concerns about violence and, in an evolutionary discourse, the atavism of children into uncivilised, brutal beings. Like the scientists in the anti-germ warfare campaign, children as socialist subjects faced the danger of improper intimacy with the abject.

Ideologically, the magnifying power of the microscope remained important throughout the socialist period to differentiate those who were truly revolutionary from those who only feigned it. At the dawn of the Cultural Revolution, the microscope would re-emerge when official newspapers such as Liberation Army News (Jiefangjun bao 解放軍報) advocated that everyone should use the "telescope and microscope of Mao Zedong Thought" to detect hidden revisionists and capitalists (MacFarquhar 2006: 47). Under the microscope of Mao Zedong Thought, scientists suffered from a more severe blow of thought reform. Many who participated in the germ warfare investigation of the early 1950s were criticised and reeducated, forced to "take a bath" (xizao 洗澡) to remove their ideological pollutants. Despite the scientists' repeated disavowal of the capitalist world and their questionable personal histories, the regime's suspicion about their uncleanness placed scientists in a forever ambivalent zone of abjection.

This paper studies how the microscope both enabled and complicated subject formation through the mechanism of "guarding life" in the anti-germ warfare campaign. By teasing out the relations between the production of the socialist subject and the making of the enemy, this paper takes seriously the binary ideology prevalent in the Cold War era and asks what it takes to sustain and interrupt the boundary. Situated in a longer history, the moment of 1952 came with the historical baggage of national trauma and left legacies in the political campaigns that followed. In contemporary China, the ideological enemy gives way to other variants of the abject in the name of urbanisation, public health, or social security. These expelled others, or "strangers" as Haiyan Lee calls them, are both repudiated and necessary for the formation of post-socialist subjectivities (Lee 2014). They hover on the borders between home and foreign land, inside and outside, clean and unclean, testifying to the never-ending processes of abjection.

I Lu Liu is Visiting Assistant Professor of Chinese at Georgia Institute of Technology. School of Modern Languages, Swann Building, 613 Cherry St NW, Atlanta, GA 30313, USA (lliu422@gatech.edu).

Manuscript received on 28 March 2019. Accepted on 14 October 2019.

\section{References}

CAO,Yu 曹禺. 1950. “我對今後創作的認識” (Wo dui jinhou chuangzuo de renshi, My understanding of my future literary creation). Wenyibao 文 藝報. 25 October 1950 .

CASID, Jill. 2015. Scenes of Projection: Recasting the Enlightenment Subject. Minneapolis: University of Minnesota Press.

CATHCART, Adam. 2006. "'Against Invisible Enemies': Japanese Bacteriological Weapons and China's Cold War, 1949-1950." Chinese Historical Review 16(1): 60-89.
CHEEK, Timothy. 2015. The Intellectuals in Modern Chinese History. Cambridge: Cambridge University Press.

CHEN, Shiwei. 2009. "History of Three Mobilizations: A Reexamination of the Chinese Biological Warfare Allegation against the United States in the Korean War." The Journal of American-East Asian Relations 16(3): 213-47.

DIKÖTTER, Frank. 2010. Mao's Great Famine: The History of China's Most Devastating Catastrophe, 1958-1962. New York:Walker\&Co.

DOUGLAS, Mary. 1984. Purity and Danger: An Analysis of Concepts of Pollution and Taboo. London: Routledge. 
GROSS, Miriam. 2016. Farewell to the God of Plague: Chairman Mao's Campaign to Deworm China. Oakland: University of California Press.

HARRIS, Sheldon H. 2002. Factories of Death: Japanese Biological Warfare, 1932-1945, and the American Cover-up. Revised edition. New York: Routledge.

HE, Shichang 何世長. 2010. “朝鮮戰場反細菌戰親歷記” (Chaoxian zhanchang fan xijunzhan qinliji, My experience of the anti-germ warfare in the Korean War). Jianghuai wenshi 江淮文史 4: 53-5.

HO, Denise. 2017. Curating Revolution, Politics on Display in Mao's China. Cambridge: Cambridge University Press.

KRAUS, Charles. 2016. "Researching the History of the People's Republic of China." Cold War International History Project. Working Paper \#79, Woodrow Wilson International Center for Scholars: Washington, D.C.

KRISTEVA, Julia. 1982. Powers of Horror: An Essay on Abjection. New York: Columbia University Press.

KWON, Nayoung. 2015. Intimate Empire, Collaboration and Colonial Modernity in Korea and Japan. Durham: Duke University Press.

LAN, Xiang 藍翔. 2001. “經歷烽火硝烟的志願軍'預防註冊證”' (Jingli fenghuo xiaoyan de zhiyuanjun "yufang zhucezheng", The "certificates of vaccination" for the People's Volunteer Army). Shanghai dang'an 上海檔 案 2: 38-9.

LATOUR, Bruno. 1987. Science in Action: How to Follow Scientists and Engineers Through Society. Cambridge: Harvard University Press.

LATOUR, Bruno. 1988. The Pasteurization of France. Cambridge, MA: Harvard University Press.

LATOUR, Bruno. 1990. "Visualization and Cognition: Drawing Things Together." In Michael Lynch and Steve Woolgar (eds.), Representations in Scientific Practice. Cambridge: MIT Press.

LEE, Haiyan. 2014. The Stranger and the Chinese Moral Imagination. Stanford: Stanford University Press.

LEl, Sean Hsiang-lin. 2014. Neither Donkey Nor Horse: Medicine in the Struggle over China's Modernity. Chicago: University of Chicago Press.

LEITENBERG, Milton. 1988. "Resolution of the Korean Biological Warfare Allegation." Critical Review in Microbiology 24(3): 169-94.

LEITENBERG, Milton. 1999. "New Russian Evidence on the Korean War Biological Warfare Allegations: Background and Analysis." Cold War International History Project Bulletin March: 180-200.

LOCKWOOD, Jeffrey. 2009. Six-legged Soldiers: Using Insects as Weapons of War. Oxford: Oxford University Press.

LYNTERIS, Christos. 2013. The Spirit of Selflessness in Maoist China: Socialist Medicine and the New Man. London: Palgrave Macmillan.

MACFARQUHAR, Roderick, and Michael SCHOENHALS. 2006. Mao's Last Revolution. Cambridge: Belknap Press of Harvard University Press.

MIRZOEFF, Nicholas. 2011. The Right to Look: A Counterhistory of Visuality. Durham: Duke University Press.
QIU, Weifan 装維蕃. 1993. 歲月散記 (Suiyue sanji, Random notes of the years). Beijing: Kexue puji chubanshe.

QUINN, John. “我被迫參加美國華爾街發動的非人道的細菌戰經過” (Wo beipo canjia Meiguo Hua'er jie fadong de feirendao de xijunzhan jingguo, How I was forced to participate in Wall Street's inhumane scheme of germ warfare). Renmin ribao, 6 May 1952.

ROGASKI, Ruth. 2002. "Nature, Annihilation, and Modernity: China's Korean War Germ-Warfare Experience Reconsidered." Journal of Asian Studies 61(2): 381-415.

ROGASKI, Ruth. 2004. Hygienic Modernity: Meanings of Health and Hygiene in Treaty-Port China. Berkeley: University of California Press.

Shanghai dianzi yibiao gongye zhi bianzuan weiyuanhui 上海電子儀 表工業志編纂委員會. 1999. 上海電子儀表工業志 (Shanghai dianzi yibiao gongye zhi, Development of electronic instrument industry in Shanghai). Shanghai: Shanghai shehui kexueyuan chubanshe.

SCHMALZER, Sigrid. 2008. The People's Peking Man: Popular Science and Human Identity in Twentieth-Century China. Chicago: University of Chicago Press.

SHAPIRO, Judith. 2001. Mao's War Against Nature: Politics and the Environment in Revolutionary China. Cambridge: Cambridge University Press.

SHI, Dongshan 史東山. 1952. “關於'反對細菌戰' " (Guanyu “Fandui xijunzhan", On "Oppose Biological Warfare"). Dazhong dianying 大眾電 影 15 .

SUMMERS, William C. 2012. The Great Manchurian Plague of 1910-1911: The Geopolitics of an Epidemic Disease. New Haven:Yale University Press.

TANG, Xiaobing. 2015. Visual Culture in Contemporary China: Paradigms and Shifts. Cambridge: Cambridge University Press.

WANG, Jiaji 王家楫. 1952. “批判我的舊思想” (Pipan wode jiu sixiang, Criticising my old thought). Kexue tongbao 科學通報 3: 14-6.

WU, Zhili 受之理. 2013. “1952年的細菌戰是一場虛驚” (1952 nian de xijun zhan shi yi chang xujing, The bacteriological war of 1952 is a false alarm). Yanhuang chunqiu 炎黃春秋 11:36-9.

YU, Fengzheng 于風政.2001. 改造 (Gaizao, Thought reform). Zhengzhou: Henan renmin chubanshe.

Zhongguo renmin baowei shijie heping weiyuanhui 中國人民保衛 世界和平委員會. 1952. 美國政府細菌戰罪行展覽畫冊 (Meiguo zhengfu xijunzhan zuixing zhanlan huace, Pictorial of the exhibition on bacteriological war crimes committed by the government of the United States of America). Beijing: Baowei shijie heping weiyuanhui. 